\title{
MAN AS RELIGIOUS, RATIONAL, FREE AND CONSCIOUS BEING
}

PhD. Marin BUGIULESCU,

Member of Dumitru Stăniloae Scientific and Interdisciplinary

Research Center, Valahia University, Târgoviște,

ROMANIA

\section{Email: m bugiulescu@yahoo.com}

\section{ABSTRACT}

This study presents the philosophical and humanistic outlook and the Christian thinking about human nature, and in this perspective the man is a rational, conscious and free being, he is in permanent dialogue with God, the Creator of the world. At the heart of rational thinking has always been the man seen as a religious, rational, free and conscious being. As a clarification of evolutionary thinking, Christianity speaks of evolution within the species, and not from one species to another. God is a pretended, impersonal existence, or a principle of the world for philosophy and scientific theories, and even for other religions. Unlike these, the Christianity, as revealed religion, originates from the reality that God exists and because He has truly been revealed to man in the context of time and creation. The key concepts specific to the Christian religion are: God the Holy Trinity, the creator of the world and man appeared from nothing (ex nihilo), man bears the icon of God and is destined for holiness. Based on these realities, no other being in the universe, known or unknown, was, is or will ever be of a greater importance than man, because there is no other being created with the icon of God, for the fulfillment of which God assumed the human nature, saving and sanctifying it through Christ.

Keywords: man as rational being; conscious; free; philosophy; theology; Christianity;

\section{INTRODUCTION}

Man is (ab initio) from the very beginning a religious being, although some opinions or scientific ideas emphasize the opposite, claiming that the religious phenomenon has appeared in the evolution of thinking and living. As a fundamental and rational discipline, philosophy in the understanding of the theory of existence (ontology) formulated over time responses to the religious phenomenon, accepted by virtue of logic as forms or current thoughts specific to man as a conscious-cognitive being.

From an etymological point of view, the word religion comes from Latin and has different meanings. For example, Cicero deduces it from relegěre (to recite, to meditate, to reflect), whereas Virgiliu from relinquerre (to remain, to distinguish, to put aside). Lactantius and most philologists and theologians infer the word religion from religāre (linking again or mutually uniting). In fact, religion is the free and conscious connection of man with God, and includes the relation to divinity through knowing Him, but also knowledge of the realities of life. In all historical times, belief in divinity has guided mankind, and religion has played an essential role in human life from the moment of coming into the world and continuing to death. Religious life is present in all peoples of the world, no matter of the degree of institutional and social development and organization. The existence of religion is 
dependent on the question of man's existence and the knowledge of divinity within the monetary peoples or divinities in the case of the polytheistic ones. Mircea Eliade argues that

"Religion begins where there is total revelation of reality: revelation at the same time of the sacred - of what is excellence, of what is neither illusory nor evanescent - and of man's relationship with the sacred (...) that places the man right in the heart of the real" .

The origin of religion has been analyzed and conceptualized over time in three theories: evolutionary (developed with man), rationalist (based on human reason that invented religion) and nativist (religious ideas are born in the mind of man). At the heart of rational thinking has always been the man seen as a religious, rational, free and conscious being. As a clarification of evolutionary thinking, Christianity speaks of evolution within the species, and not from one species to another. According to the Darwinist evolution, man is traced from a form of anthropoid, vanished, but still has representative evolutions in current anthropoids, such as the gibbon. There are also naturalists who contradict this idea by supporting evolution in different species. Others talk about parallel developments, from which people appeared in different places and periods. Of course, all these suppositions cannot be called theories because there is no evidence of any kind, but only speculation, given by some institutions and scholars, biologists and anthropologists as value of truth, deliberately ignoring the historical reality of man as a religious being who has always had the idea of a creative divinity.

\section{RATIONAL AND PHILOSOPHICAL REFLECTIONS ON HUMAN NATURE}

Analyzed from materialistic-dialectical thought perspective, man is a continuous challenge investigated according to the scientific field and defines unanimously as the maximum result of evolution. As a paradoxical personal religious being, man is the bearer of the divine icon, by virtue of which his status and role in creation is that of a conciliatory ring between transcendent and immanent. From this perspective, man is not only an object of science of God, but also a creative subject and a bearer of science, because ontologically, by reason, his conscience and his freedom are oriented towards knowledge, discovery and rediscovery, and more chosen to his Creator-God. This orientation acquires a real content supported by the logical knowledge of the cosmos and the prophetic being, but especially by the revealed faith that does not ignore the logical knowledge that it deepens through the mystical or spiritual knowledge.

The methods and means of dialectical knowledge are multiple, but if the result remains circumscribed in their sphere, then man is not regarded as a whole (material and spiritual), but as a conceptually defined part physically, anatomically, psychologically, sociologically etc. An essential contribution to this is, especially lately, scientific technology and micro-robotization, genetic manipulation, and many other tools for doing all sorts of experiments. But there is a dilemma in this, a pertinent question: Does man use the technique? Or does the technique use man? All these autonomies and totalizing technologies of science that claim to go up to the created and uncreated tooth border are necessary, to the "God's particle", of course a "god" created and divided into several, depending on the stage of the research.

\footnotetext{
${ }^{1}$ Mircea Eliade, Mituri, vise şi mistere (Mythes, rêves et mystères), trad. Maria Ivănescu and Cezar Ivănescu, Bucureşti, Univers Enciclopedic Gold, 2010, p. 12
} 
From a rational-philosophical point of view we can speak of a series of features that are specific to human nature, on which the material, cultural and psychological evolution of man was based. As a rational and conscious being, man has always asked questions about both the outer world (the surrounding world) and the inner one (the world conceived in the soul or the personal self). This openness to the world and to the human being has been analyzed since the Antiquity, being a fundamental issue both for the religious and philosophical world, and more recently for various scientific researches.

By virtue of rational power, philosophy has highlighted the superiority of human nature. Man has the quality of being rational. The origin of conceptualization ${ }^{2}$, as claimed by Plato and Aristotle, is given by man's ability to look at the world and be amazed, which makes him wonder: What are they all about? This state of astonishment and wonder in front of the world did not appear in the historical time but native is in the deepest structures of man (amazement, the desire to know only for the sake of knowing, doubt the conscience of the precariousness of the human being) that have remained the same along the axis of time, giving it its self-identity. Plato speaks, in the Republic ${ }^{3}$, about the three parts of the human soul: the rational, the active and the prudent. The rational part is the one that distinguishes the man from the animal and is qualified as the highest part of the soul, having a divine source and being immortal. The active part works ideally with the rational one, and one of its own. The appealing part refers to natural impulses, to bodily desires, and is, in the hierarchy of soul, on the lowest level, it brings man closer to instincts of animals. „Body, soul, mind: to the body belongs the sensations, the soul - the impulses, the minds - the teachings"4

These intrinsic capacities of man, and inherent to the soul, made him a wisdom-wise and creator of wisdom, philosopher.

"Pythagoras ... saying that no man is wise, but only the god. Philosophy was formerly called wisdom, and the professor was called wise, to show that he had reached the highest degree of soul perfection; the philosopher was the lover of wisdom",5.

What characterizes human nature is, first of all, wisdom as an intellectual, moral and spiritual reality, as the union between the sides of the soul, held in a balance as stable as defined by virtue. Heraclitus of Ephesus (540-470 BC), expresses all these: „wisdom is one thing: to have the ability to know all things through the intercession of all things; wisdom means .... to conform to the truth by obedience to the nature (physics) of things" $"$. The entire contemplative, rational and logical process was expressed by the theoretical extent. Conceptual theory in antiquity has been formulated on the basis of the Greek verb theoréo $(\theta \varepsilon \omega \rho \varepsilon \dot{c} \omega)$ which I consider that involves the following operations: to look, contemplate, examine or consider, but also derived meanings: theoréion, which aimed at the place where the audience contemplates the representation of the actors ; theoréma, which was a spectacle, but also an object of scientific observation; theoretical, visible (in itself but also with the mind's eye), that is, what is comprehensible, which can be understood immediately and instantaneously; theoretical, contemplative, intellectual.

\footnotetext{
${ }^{2}$ Karl Jaspers, Texte filosofice, (Philosophical texts), Bucureşti, Politică, 1986, p. 5

${ }^{3}$ Platon, Republica, cartea a-VIII-a, 543a - 592b, Enciclopedică, Bucureşti, 1986, p. 347

${ }^{4}$ Marcus Aurelius, Gânduri către sine însuşi, (Meditations), Cartea III, 16, Traducere, prefaţă şi note de Cristian Bejan, Humanitas, Bucureşti, 2013, p.113

${ }^{5}$ Diogene Laertios, Despre vieţile şi doctrinele filosofilor (On philosophers' lives and doctrines), Bucureşti, Editura Academiei, p.118.

${ }^{6}$ Ion Banu, Filosofia greacă până la Platon (,Greek philosophy to Plato) Vol. I. Partea a 2-a, Bucureşti, Ştiinţifică şi Enciclopedică, p. 321-373
} 
In the paradigm of intellectual thinking, formulated on the scale of historical evolutions, man is the source of ideas that, in the horizon of a potential existence, postulate new realities that do not preexist before his own activities of knowledge, except in the form of preconditions, of simple virtualities.

\begin{abstract}
"Where there is an object, there is thought. Is it then the thought of something and the object another thing? No, what is the subject exactly is the thought. If the object was one thing and the thought was different, then there would be a dual state of mind. So the object itself is just thought. Can the thought then analyze the thought? No, thought cannot analyze the thought. As the edge of the sword cannot cut itself and the tip of a finger cannot touch itself, so a thought cannot conceive of itself",
\end{abstract}

This approach was summed up by Descartes in the Cartesian formula: "I think therefore exist." Ancient thinking placed man in the context of a seen world, conceived as a cosmos, respectively, as an order with its own rationality, opposed to chaos. The first to use the word cosmos to characterize the universe, was Pythagoras. Heraclitus conceives cosmic order through logos, understood as the Natural Law. But the world, the cosmos has an arché, (beginning, principle) that expands through unity and diversity, through harmony. Starting from the context of creation, the principle of the world (arché) for Thales of Miletus is water. The Miletus School through Anaximenes and Anaximandros identified the world's nature in other elements: air and apeiron (infinite, unconditional, endless), respectively. Then Pythagoras School (580-500 BC) conceives the monad that underlies everything that exists. The logos of Heraclitus in Ephesus are identified by fire (pyr), understood as the everlasting entity responsible for all that is happening in the world, from which all things come, and all of it returns.

With Parmenides (515-450 BC), thinking is placed as a principle of being, for it is meant to think. This means that the definition of being is made on the basis of the formal conditions of thought. The logical structures of thought create the outer and inner universe, and logically constrained we must conclude that the being exists. Plato's dialogical thinking ${ }^{8}$ (428-347 BC) starts from the inner forces of man who has access to the truth. Truth preexists in the mind of man in a latent, undefined form, and through dialogue reveals it in theories. Knowing this means knowing something I knew before. The pre-existence of truth has generated the hierarchy of the world or the Theory of Ideas exposed in the dialogue of the Republic, the 7th book. Conceptually Plato talks about three ideas: 1. the visible world, 2. the intelligible world, 3. the idea of participation that reflects the relationship between the One and the Multiple. Starting from the distinction between phenomenon-appearance and essence, Plato conceives the world of ideas as a transcendent, eternal and invisible world different and separate from sensitive things. Knowledge of ideas is the pre-existent appanage of man who through the soul (nous, intelligence, thinking) before being united with the body has access to the reality of the universe, of the Idea and thus makes the transition from general to universal.

Aristotle (383-322 BC) through critical reporting to other philosophers, including Plato, instills a new way of thinking, namely metaphysics. From the etymology of the metaphysical word: meta (after) and physike (nature, essence) by the nature of things, by essence, we understand that we are talking about knowing things in ourselves. Man has the need for knowledge in the structure of soul life. The Arché explains both the unity of the

\footnotetext{
${ }^{7}$ Alain W. Watts, Calea Zen, (The Zen Way), Humanitas, 1997, p. 77

${ }^{8}$ Expressed in 28 dialogues and 13 letters (of which only 3 are authenticated).
} 
world and diversity, it is in all its essence that makes the world an order and a unity. "The common feature of all these principles is that they are the first starting point for which one thing is, is born or is known" (Metaphysic V, 1; 1013a). Starting from these particular realities, man knows and is known. The problem gets shades in relation to purpose. In Politics, Aristotle shows that the purpose of man is to lead a happy life. Man is an eminently social being, because it is in his nature to live in the family or to associate with others to live happier. The purpose and purpose of man is therefore the fulfillment of his nature. The world is composed of infinite things, phenomena and relationships, but each retains its own individuality. The world is made up of individual things and therefore there are not two identical things, but all these particularities are in harmony. In Aristotle's view, the quest for happiness (through reason) and man's predisposition to happiness understood as supreme is the native capabilities that man has.

The relationship between the One and the Multiple, sustains the harmony and symbiosis between man and created ones, on the one hand, and divine man on the other. The idea of harmony stems from the concept of Pythagoras, developed by A. Koestler, through which the universe is considered a lira or a city whose emperor is man. This compatibility between man and nature, this connection between the individual being and the universe, results from the fact that the world was created for man, an idea promoted by the Stoics, and emphasized by Mark Aurelius who says:

"Anything that fits me, world, suits you, nothing happens to me too soon or too late for you to happen at the right time. Forminus is a fruit whatever your season produces, a nature: everything comes from you, there is everything in you, in you everything turns" 9 .

With the economic, scientific and technical development of the world, following the idea promoted by Thales of Miletus, the man of European philosophy, seeks his origin in explaining the phenomena of nature, in the action of a natural factor and not in the action of a divinity (determinism, evolutionism, creationism).

In Renaissance there is a turning point, appealing to the ancient classic spirit, where man occupies the central place. Nature is presented as the perfect temple of God the Architect, - Pico de Mirandola (1463-1494), man is free, can be created by himself; his supreme mission is the discovery of the divine dwelling in him. After about two hundred years in the era of Enlightenment Blaise Pascal (1623 - 1662) considers that man is a rational animal, equipped with the power to rationalize, think, but is a weak being: "Man is but a reed, the weakest of nature; but it is a cute reed". René Descartes, the founder of classical rationalism, defines man as a dual, physical and material being as (a stretched substance and a thinker substance), from the point of view of the essence which is the thought expressed by the formula "I think, therefore exist."

With the passage of time in the spirit of modern thinking, the description of the human nature in terms of knowledge focused only on the powers of man's mind because of the autonomy of science and technology that pretend to explain everything that exists. If ancient thinking spoke of a human nature full of transcendental abilities, the knowledge of the transcendent infinity, modern thinking puts in the center the instinct-dominated instinctual man who gives a permanent struggle for survival. The only generally valid explanation is given by technique, empirical research, science. If the thinking of the ancient philosophers also implied some religious experience with rationalism and modern

\footnotetext{
9 Marcus Aurelius, Gânduri către sine însuşi, (Meditations), Cartea IV, 23, Traducere, prefaţă şi note de Cristian Bejan, Humanitas, Bucureşti, 2013, p. 127
} 
empiricism, religion is excluded from the systems of knowledge of man and the world, although in the recent period certain steps have been taken to establish a dialogue between science and faith. By replacing God with the scientist, Renaissance has contributed to intellectual desacralization and dehumanization of man.

Thomas Hobbes, the fundamental work Leviathan where he formulates the concept of war against everyone (bellum omnium contra omnes), gave the tone of autonomy to the human nature that identifies itself in the context of creation through the instinct of selfpreservation. Man is an asocial being, who lives on the basis of a contract and has a natural attachment to autonomy. People are before the state, the society. In the natural state of nature, the instinct of self-consciousness generates selfishness and violence against others. John Locke (1632-1704), in Human Understanding Essay ${ }^{10}$ excludes natural ideas present in the mind or in human consciousness. He claims that the human mind is, at birth, like an empty board (tabula rasa) on which information begins to be written through experience. His predecessor Fr. Bacon (1561-1626) based on the inductive method bases any scientific knowledge on the observation data by supporting empiricism or the argument of actual experimental facts.

Jean-Jacques Rousseau, in a pessimistic spirit, starting from the idea that society is the one who perverts nature speaks of "the wild thing" a concept presented in book Discours sur l'origine et les fondements de l'inégalité parmi les hommes. Man also has defining sentiments, for example mercy, but by survival he has mastered animal instincts.

"The savage lives for himself; the sociable man who is always outside knows not only to live
according to the opinion of others and draws the feeling of his own existence only out of
their judgment ... /. This is not the natural state of man, but the spirit of society and the
inequality that it inspires are those that change and alter our natural inclinations". 11

It is society that perverts human nature. David Hume (1711-1776) in his work, entitled Research on the Human Intellectuality, argues that „man is a rational being, but the limits of the powers of the human intellect are so narrow that we cannot hope too much about both the extent and the certainty of his conquests. Man is a sociable being to the same extent as it is rational."12

The desacralization of medieval life on the religious, political and cultural realms has emerged in a universal economy, in a universal science (scholastics), in a jurisprudence and a universal social order, hierarchically divided, dividing values into an individualistic diversity. Renaissance puts the biological man and his beauty at the forefront. At this time, literature and philosophy focus on "homo liberalis", the truly liberal man defined by Rabelais and expressed in the formula "do all you want".

Absolutely all human research believes that it has a number of cognitive structures that allow and encourage learning through experience, starting with language and going up to the most advanced notions. The system of thinking, the articulated language, the ability of the sentient feelings, distinguishing the man from the rest of the animals and placing him in a higher position, these are necessary conditions, but not sufficient for the fulfillment of the human being. In the book The Human Place in the Cosmos, Max Scheler states that "being

\footnotetext{
10 John Locke, Eseu asupra intelectului omenesc, (Human Understanding Essay), vol. I-II, Bucureşti, Ştiinţifică, 1961

${ }^{11}$ Jean-Jacques Rousseau, Discours sur l'origine et les fondements de l'inégalité parmi les hommes, Paris, Gallimard, Bibliothèque de la Pléiade, 1964, p. 140

12 David Hume, Cercetare asupra intelectului omenesc, (An Enquiry Concerning Human Understanding), Ştiinţifică şi Enciclopedică, 1987, p. 91
} 
man is to say a powerless reality". ${ }^{13}$ Also Martin Heidegger, after a period of relativization of the axiological notions, in the Being and Time, published in 1927, replicated the problem of ontology and phenomenology (human being), through the Dasein idea (in German "yes" means here and "Sein" is being). The Dasein conception, giving up all previous knowledge and ideas, wants to start from a zero point and claims that man is born as "tossed" into the world to death. Man has no choice in the first instance, he does not choose to be born. Throwing is essential to the human being. Dasein is defined by a threefold state: the design (the man as a possible), the throwing (the man as a beast who does not choose whether or not to be born) and the one of the fall (the fact-to-be-fell). This explains the loss of man by contamination with sensitive reality, speaking of transcendental preexistence, to overcome the concepts by which man is defined from the biological perspective as superior animal.

Without confusing them because they are different in this issue, we are hurting some essential Christian-specific ideas. The special and personal relationship that man has to have with God is very clear from the act of biblical creation, from the fact that all other creatures were made by the power of the word of God: "And God said ..." (Genesis 1,3,6,9), while man is created by a special act through the direct participation of God the Holy Trinity. The crucial transition from animal to human to Christianity is not a mechanical or evolutionary act, nor does it arise through a commandment but a direct and mediated action of God in which the breath of life of the Spirit creates the conscious and free being MAN. Thus, man is the individual and universe that embodies the power to participate in infinity, being a microtheos, but by falling into $\sin$ is conscious that it is not infinite itself, always living, with its indefinite, insufficiency, relativity, boundaries of its own nature but united with aspiration and thirst for absolute:

"...he is created by God, but he is not altogether devoid of participation in God and parted from Him. He is not thrown into a world, separated from God, as Heidegger said. It is objectively sustained in existence by the infinite God and cannot not subjectively tend towards the Absolute."14

With these ideas, we are going to the next chapter that will present the Christian conception of man understood as a rational, conscious and free being in dialogue with God the Creator.

\section{MAN, RAISONAL, CONSCIOUS AND FREE DIALOGUE CONVIEW WITH GOD. THE WAY FROM NEFINITY TO BEING}

The approach from this part of the work is the one given by divine revelation in the Bible. The key concepts are Christian ones that speak of the existence of a Holy Trinity God, the creator of the world and man of nothing (ex nihilo). The ex nihilo concept of making the world philosophically ontological is unacceptable. Rational and limited thinking cannot conceive of the existence of non-existence, and on the other hand doing nothing requires a term beyond itself, of material reality. Paradoxically, in the plane of metaphysical thought, being and non-existence are in identity and difference at the same time.

God is a pretended existence, impersonal or a principle of the world for philosophy and scientific theories, and even for other religions. Unlike these, Christianity as revealed religion originates from the reality that God exists and because it has truly been revealed to man in the context of time and creation.

\footnotetext{
${ }^{13}$ Max Scheler, Poziția omului în cosmos (The Human Place in the Cosmos), Paralela 45, București, 2001, p. 56

${ }^{14}$ Pr. Prof. D. Stăniloae, Chipul nemuritor al lui Dumnezeu, (The Immortal Icons of God), Mitropolia Olteniei, Craiova 1987 , p. 37
} 
In particular, creation and humanity in general, as revealed by divine biblical revelation explained by patristic theology, is the work of divine love brought from nothing to existence. A personal God, more precisely Tri-Personal, is without a beginning and an end, and reveals himself to his special creation, man. We do not speak of God as an unconscious, impersonal force flowing into and over the world, merging with it, as in pantheism, but by a transcendent and incapable of God's being, and immanent or cognizable after works. Only such an ontological, loving, eternal Being can create a being capable of relationship and love, in a continual knowledge and existence, namely, man. In Christian theology, God is "what is," (ó óv) because he has the quality of a Personal Being, and his existence does not depend on anything, not even on His Being or Nature, for His Being or Nature does not make His existence obligatory. His absolute will and liberty is accomplished as everlasting love and interpersonal communion, that is why he was blessed as follows: "God is love" (1 John 4:16). The divine meaning of Divine Existence is "BE LOVE": , what is constituted in his personal Existence, in the Trinity of Personal Hypostasis, which makes the Divine Being, Divine Nature or Divine Being, a life of love, that is, free of any necessity ..."15.

Man is created by God out of love, so begins somewhere and once, as a single subject, individually, as a conscious, free and rational personal being. "And God said, Let us make man in the likeness and likeness of Our Lord, that He may possess the fish of the sea... and all the earth" (Genesis 1:27). Among all creatures, God alone creates God in particular. Man is not the result of a divine commandment as God created all other beings, things and universes, for the earth was not able to produce a being endowed with reason, freedom, conscience and will. God, through His great power and love, created man in the icon of Divine Glory, and gave him the likeness to which they must reach by their own work. Analyzing the scriptural text, we see the distinction between the singular "and said" and the plural "Let's do," man (singular), in our own (plural) icon of divine and likeness; and we come to the conclusion that man is a subject of the "unseen God" (Colossus 1:15). Then Scripture tells us the woman's doing precisely to elucidate what the ontological rendering of the divine icon is: "And God made man in his icon and made him a man and a woman" (Genesis 1: 27). The distinction between man and woman is of course unrelated to the ontological and indelible date of God's icon in man, for God is not divided into masculine and feminine, that is why His icon extends over the whole human nature. In Book of Faith 2,7 there is an account of how God created man: "Then the Lord God took the dust of the earth, and made man blow a breath of life before him." What is important is not the material act, but the fact that human nature has been dual constituted from the flesh and soul through the breath of life of divine grace: ,for the flesh (man) to ascend to godliness and one grace to guide and walk through all creation..". ${ }^{16}$ The Greek soul-translated Hebrew nephesch has many meanings and would mean, in general, everything that is alive, even animals, yet it is not justified to define man's philosophy as RAW ANIMAL - because the spiritual nature of man is not based on body, soul, and reason, but on the quality of person. The person is linked ontologically to the creation of man in the icon of God and the dialogue, grace with God, the person embraces the human nature in its psycho-somatic, bodily and soul integral. Through personal spiritual quality, man is destined for deification.

\footnotetext{
${ }^{15}$ Christos Yannaras - Abecedar al credinţei (Elements of Faith: An Introduction to Orthodox Theology),, trad, Preot Dr. C-tin Coman, Bizantină, Buc. 1996, p.78

16 Sfântul Grigore de Nyssa, Marele Cuvânt Catehetic;VI,2, trad. Pr. Grigore Teodorescu, Sofia, Bucureşti,1938, p. 34
} 
For Christian theology the main quality of man given by God lies in the fact that man is a personal being endowed with reason, will and sentiment, with knowledge and selfconsciousness, which links him to the past, present and future, but also to self, fellow, creation, and God. In the spirit of the terminological explanations:

\begin{abstract}
"the person is not a nature [...]. In essence, what makes us different animal beings is the existence of our person [...], the person exists only in beings endowed with reason [...]. It is the intangible thing that the Incarnation of the Word has given to men and made them receive Grace [...], is a mystery, the mystery of the seal upon human, earthly nature" ${ }^{, 17}$.
\end{abstract}

As a personal being in dialogue with God man is the crown and the beauty of creation, in which divine love is concentrated, which gives him a special status, gives him value and sense to all other ceremonies. On this logic, no other being in the universe, known or unknown, has had and will not be of greater importance than man, because there is no other being created in the icon of God, for the fulfillment of which God assumed it saved and sanctified it through Christ.

Man is the central being of the action, its material and spiritual axis. Patristic theology bases the teaching of man on his icon of God, (ontological evidence) and the likeness of God defined as perfection, through the sacredness of holiness as the fulfillment of man and man. Thus, man is not only a part of the world but also its synthesis. Man is the consciousness of creation, capable of contemplating and determining it. As St. Gregory of Nyssa shows, man's majesty is not in the likeness of the created, he is not merely a synthesis of the world in a small, microcosm, for this quality is "both mice and mosquitoes ..." ${ }^{18}$. The majesty, man's superiority in the world is given by the ability to contemplate God (capax $d e i$ ) by being an icon of God (imogo Dei), but especially by the finality of his existence, namely the acquisition of the state of holiness.

Man is a rational, free and conscious being who has the purpose of accomplishing the ultimate goal of the universe, he is a macrocosm, and the world can become a macroanthropocosm through man. Human solidarity, with nature, generates the relationship and harmony of the soul with the body, with which it forms a unity and tends to perfection. According to the anthropogenesis narrated by Moses, the divine icon of man and the likeness of God implies not only an opening to God, but also a permanent dialogue with all creation, because in the microcosmic structure of human nature its dual constitution, body-soul, as well as the fundamental duality of the created material and spiritual universe.

The divine icon in the men as a divine seal is the meeting point between divine and human. The divine face of man in his integrity refers to the nature of the whole man (body and soul), to his person who has a tension and an aspiration to the likeness of God, that is why man is a being of dialogue, of communication, of a social and sociable.

The harmony and unity of creation is given by the fact that all the existences within it are in relation to each other than by the fact that they all distinguish themselves by presenting a unity in diversity and in the last analysis by a general reason of the entire creation, cosmic by Christ, the archetype of man was made because:

\footnotetext{
${ }^{17}$ Alexandros Kalomiros, Sfintii Parinti, despre originile şi destinul cosmosului şi omului,( The Holy Fathers on the Origins and the Destiny of Cosmos and Man), ed. a II-a, traducere Ioan Ică, Deisis, Sibiu 2003, p. 58-62

${ }^{18}$ Sfântul Grigore de Nyssa, Omilii la Facere, XVI, trad. Pr. T. Bodogae, în P.S.B. 30, Bucureşti 1998, p. 46
} 
"all that are after God have their existence from God, through each are in every being according to the true Reason. Firstly, because none of the existence, either of the very honest and superior ones, is loose from the general relation to the honest" ${ }^{, 19}$.

The position of man in the cosmos is central, man appears as the synthesis and crown of creation, being created in the icon of God (Genesis 2:7), being solidarity with the earth, with the whole creation, but also with God.

All Christian thinking views man in the perspective of Christ the Son of God Incarnate. Christ has one person who has two human beings: divine and human. Christian theology shows that the Person of Christ is contained entirely of divinity from eternity and human nature as the incarnation of the Holy Spirit and the Virgin Mary, indicating that Christ assumed human nature as a species apart from sin, but talk of the human nature altered by $\sin$. In the perverted state of sin, man as a person who assumes individual human nature remains an icon of God, but his face does not have a normal functioning structure, and he is also alert. The logical and ontological sense of assuming the whole of human nature by Christ is precisely its fulfillment, or the elevation to the state of continual being defined by the term of deification. This is the result of a permanent relationship through divine grace or energy, and it does not mean ontologically a change of being in an evolutionary sense through the appearance of another species. Devotion or state of holiness shows human nature at its peak and in this state man is conscious and free of depression. Devotion is acquired through union with Christ, is the result of personal choices and experiences, but with sociocommunity effects.

Universal, the whole human nature has been perfected through the Person and work of Christ in whom the Holy Trinity works. This objective is accomplished by the Christian teaching about salvation in Jesus and acquired on a personal level by those who accept a consciously and freely relationship with Christ being come to fulfillment, to acquire holiness. So the man through whom Christian theology sees and explains the world is Christ, the Son of God, the Incarnate Logos, the Reason in which the purposes of creation are in unity, that is why Christ is God-Man. Through Christ, St. Basil the Great emphasizes the inner bond between God and creation, because God: "not only entered into the whole being of the world but put all its parts in harmony with one another and made a harmonious whole, appropriate and agree with Him" ${ }^{20}$. The relationship between humanity and divinity is not that of matter and object, but of love as a person-to-person, accomplished by the presence of grace that transforms and sanctifies man and creation.

The presence and work of God through grace in creation is channeled, which man, who ontologically through divine grace has planted in its nature the icon of Christ, and hence a religious, internal life through introspection, but also an external one by referring to the fellow in which it is present God, with whom man has a dialogue and a permanent meeting.

\footnotetext{
"If you remember yourself - says St. Basil the Great- you no longer need to discover God in the other creatures; you will contemplate in yourself as in a microcosm, the great wisdom of your creator. From your intangible soul you will know that God is intangible ... he admires Master for the wonderful icon by which he has bound your soul with your body .... Of all the living creatures, only man created him with the faculty of standing, so that you may know, from his position, that your life is a divine origin ..., the quadrupeds look to the ground ...; only man has his eyes ready for heaven .....21
}

\footnotetext{
${ }^{19}$ Sfântul Maxim Mărturisitorul, Ambigua, trad. Pr. D. Stăniloae, în P.S.B. 80 E.I.B., Bucureşti 1980, p. 267

${ }^{20}$ Sfântul Vasile cel Mare, Omilii la Hexaimeron, I, 7, în PSB., nr. 17, IBM., Bucureşti 1986, p.78

${ }^{21}$ Sfântul Vasile cel Mare, Omilii şi cuvântări, III , VII-VIII, pp. 373-374
} 
This reality shows that man is the only creature made to contemplate God (capax and imago Dei), whose dialogue partner God can become, but not a nature with God, but the fulfillment of human nature. The resemblance or fulfillment of the human being as the supreme mission and purpose of man represents the ontological state of human nature: "in some respects is the development of grace of potency, planted in man, especially that the likeness is but a development of the icon"22 accomplished eschatologically, because in this life it is only anticipated. Undergraduate characterizes a situation "in-the-life" but current, but the perfect human unity is related to an eschatological reality, being conceived as a "stability" in divinity, when it will be a "new heaven and a new earth" (II Peter 3:13). This is the only possible evolution from the Christian perspective, understood ontologically within species, and not between species. So, in temporal earthly man, man remains a man no matter how religiously, intellectually, technically and socially evolved, as well as in the eternal, temporal dimension in which he enters by death, remaining in dependence and rallying with God, felt as a continuous lack for those in the state of suffering, and as joy and endless happiness for those who are through Christ in the state of communion and eternal dialogue. This is the meaning of man as a rational, conscious, free and affective being, this is the path from non-existence to being, reached only by union with Christ, "The Way, Truth and Life" (John 14:6).

\section{CONCLUSIONS}

The fundamental questions about human nature in the ontological and the phenomenological perspective have received various answers in history. The Philosophy presents man as a rational, autonomous and contextual being, both at the personal level by disciplining the instincts and at the inter-personal level through social laws.

In the coordinates of modern thinking, the description of the human nature in terms of knowledge focused only on the powers of man's mind, because of the autonomy of science and technology that pretend to explain everything that exists. Generally, man is defined as the most advanced being, who has reached this state due to the instinct of selfpreservation or struggle for survival.

Without confusing the philosophical ideas, because they are different in this issue, with the ideas specific to the Christian religion, we must conclude that man is not just a rational animal but a rational animal deified. The site of deification or human fulfillment is potentially encompassed in every man by being created in the icon of God. Through the divine icon, man is a rational, conscious and free being in dialogue with God-the Creator.

Through man's activity, man is capable of philosophy and science. God's quality of being God's icon is native, ontological and indelible; that is, it is not lost whatever it does in life, but it also does not bring any added value. Man is born as a person and according to what he becomes a personality.

The apostle of personality, the fullest fulfillment of humanity, is accomplished by Jesus Christ, the God-man, the Paradigm and the ultimate goal of the world. Christ as the fulfillment of the human being is in a permanent opening to each and every person, because only in co-operation with Him man constructs the path from death to endless life.

${ }^{22}$ Pr. Prof. D. Stăniloae, Ascetica şi mistica, IBM., Bucureşti 2002, p. 431 


\section{REFERENCES}

[1] Banu Ion, Filosofia greacă până la Platon (Greek philosophy to Plato) Vol. I. second part, Bucureşti, Editura Ştiinţifică şi Enciclopedică,

[2] Diogene Laertios, Despre vieţile şi doctrinele filosofilor (About philosophers' lives and doctrines), Bucureşti, Editura Academiei,

[3] Eliade Mircea, Mituri, vise şi mistere (Mythes, rêves et mystères), trans. Maria Ivănescu and Cezar Ivănescu, Bucureşti, Editura Univers Enciclopedic Gold, 2010

[4] Hume David, Cercetare asupra intelectului omenesc, (An Enquiry Concerning Human Understanding), Editura Ştiinţifică şi Enciclopedică, 1987

[5] Jaspers Karl, Texte filosofice, (Philosophical texts), Bucureşti, Editura Politică, 1986

[6] Kalomiros Alexandros, Sfintii Parinti, despre originile şi destinul cosmosului şi omului, (The Holy Fathers on the. Origins and the Destiny of the Cosmos and Man), IInd ed., trans. Ioan Ică, Edit. Deisis Sibiu 2003

[7] Locke John, Eseu asupra intelectului omenesc, (Human Understanding Essay), vol. I-II, București, Ed. Ştiinţifică, 1961

[8] Marcus Aurelius, Gânduri către sine însuşi, (Meditations), trans. Cristian Bejan, Editura Humanitas, Bucureşti, 2013,

[9] Platon, Republica, Editura Enciclopedică, București, 1986

[10] Rousseau Jean-Jacques, Discours sur l'origine et les fondements de l'inégalité parmi les hommes, Paris, Gallimard, Bibliothèque de la Pléiade, 1964,

[11] Scheler Max, Pozitia omului in cosmos (The Human Place in the Cosmos), Editura Paralela 45, București, 2001,

[12] Sfâmtul Mayim Mărturisitorul, Ambigua, trad. Pr. D. Stăniloae, în P.S.B. 80 E.I.B. Bucureşti 1980 ,

[13] Sfântul Grigore de Nyssa, Marele Cuvânt Catehetic, trans. Pr. Grigore Teodorescu, edit. Sofia, Bucureşti1938,

[14] Sfântul Grigore de Nyssa, Omilii la Facere, XVI, trans. Pr. T. Bodogae, în P.S.B. 30, E.I.B. Bucureşti 1998

[15] Sfântul Vasile cel Mare, Omilii la Hexaimeron, I, 7, in PSB. Nr. 17, Editura IBM., Bucureşti 1986

[16] Stăniloae Pr. Prof. Dumitru, Ascetica şi mistica, Editura IBM., Bucureşti 2002

[17] Stăniloae Pr. Prof. Dumitru, Chipul nemuritor al lui Dumnezeu, (The Immortal Icons of God), Mitropolia Olteniei, Craiova 1987,

[18] Watts Alain W., Calea Zen, (The Zen Way), Editura Humanitas, 1997

[19] Yannaras Christos - Abecedar al credinţei (Elements of Faith: An Introduction to Orthodox Theology), trans. Coman Constantin, edit. Bizantină, Bucureşti, 1996, 